\title{
Space Law of Ukraine: Present and Future
}

\author{
Mykhailo Loshytskyi \\ Doctor of Law, Professor, Honored Worker of Science and Technology of Ukraine. \\ Private Institution "Scientific Institute of Public Law" \\ (Kyiv, Ukraine) \\ E-mail:1mikhail@ukr.net \\ https://orcid.org/0000-0003-0533-0079 \\ Sergii Koroied \\ Doctor of Law, Associate Professor Private Higher Educational Institution \\ "King Danylo University" \\ (Ivano-Frankivsk, Ukraine) \\ E-mail: koroed_sergey@ukr.net \\ https://orcid.org/0000-0001-7899-957X
}

\begin{abstract}
The newest doctrine of space law of Ukraine is formulated in the article. The authors reveal that it consists of public and private international space law applicable in Ukraine and domestic space laws, which are classified into public and private. It is emphasized that making amendments and additions to the relevant national Law "On Space Activities", which has allowed private entities to be engaged in these activities, offers great opportunities to the Ukrainian space industry. However, the transformation into a powerful spacefaring nation still requires Ukraine to overcome bureaucratic and corruption factors in a legal and organizational manner.

Keywords: space law, space activities, public laws, private laws, national doctrine, private entities, international space law
\end{abstract}

Received: October 10, 2019; accepted: November 07, 2019

Advanced Space Law, Volume 4, 2019: 50-58

https://doi.org/10.29202/as1/2019/4/5

\section{Introduction}

The improvement of the newest doctrine of the space law system of Ukraine is relevant, because Ukraine is a spacefaring nation, though its space industry development has been constrained because of space law inconsistencies. Due to the unresolved issues of the private sector involvement in space activities, the space industry has faced a number of challenges.

(C) Loshytskyi, Mykhailo, 2019

(C) Koroied, Sergii, 2019 
Primarily, this is the lack of investment. The legal literature has not focused on this problem enough. Dr. Sci. Nataliia Malysheva made a contribution to its study. However, she analysed the challenges in this sector in a bygone era.

We argue that space law of Ukraine should involve a system of international public and private laws and relevant public and private domestic laws. Therefore, the successful development of the space industry requires a legal and organizational neutralization of the destructive influence of the State Space Agency of Ukraine in this sector.

For the first time, the article comprehensively analyses the system of Ukrainian space law sources after the introduction of amendments and additions to the laws, legal regulations regarding the involvement of private entities in space activities. The article is structured as follows: first, the origins of space law of Ukraine, as one of the first spacefaring nation in the world, are revealed, and the rules of public and private international space law applied in Ukraine are under special consideration. Much of the article analyses the domestic rules of space law of Ukraine. The article ends with an analysis, coverage of the issues of the current state of affairs in the domestic space legislation of Ukraine.

\section{Origins of space law of Ukraine}

The space industry of Ukraine originated in the days when Ukraine was part of the Soviet Union. It was most active in the 1950s, when special design bureau 586 (Design Bureau "Yuzhnoye") was established in Dnipro and an industrial manufacturer of space machinery, Southern Machine-Building Plant 586, began to operate simultaneously [Dovhal', 2011]. The first flight of 8K63 (R-12) rocket on high-boiling propellant constituents, designed and constructed by them, was successful [Gorbulin, 2011]. This enabled the mass production of relatively inexpensive strategic military missiles and satellite launch vehicles. For example, on the basis of this rocket a small-lift launch vehicle Space was constructed. It could lift spacecraft weighing up to 450 kilograms into low Earth orbit up to 200 kilometers [Design, 2019].

At that time international space law developed intensively. Ukraine, as a republic of the USSR, fully adhered to the fundamental international space treaties, which were signed and ratified.

At that moment, the category "space law" occurred in the international legal lexicon. Its occurrence was associated with the beginning of space exploration after the launch of the first artificial satellite on October 4, 1957 by the Soviet Union. And since 1958, the UN General Assembly has adopted a number of resolutions on the use of outer space. Complex initial principles of space activity were formulated in the Declaration of Legal Principles Governing the Activities of States in the Exploration and Use of Outer Space, adopted by Resolution 1962 (XVIII). Furthermore, in 1967, the General Assembly of the United Nations adopted and opened for signature the Treaty on the Principles Governing the Activities of States in the Exploration and Use of Outer Space, including the Moon and Other Celestial Bodies. It provided for and developed the principles previously formulated in the Declaration [Malysheva, 2011].

It should be emphasized that both the USSR as a whole and the Soviet Ukraine failed to adopt any space law. All domestic legal regulations of the space industry was carried out according to secret by-laws and administrative regulations.

After independence, the legal regulation of the space industry, in particular on the production and launch of launch vehicles and satellites, began to be carried out by the domestic legislation of Ukraine parallel to international space law. It provided legal support for the launch into outer 
space of more than 150 launch vehicles and 377 spacecraft. Technologically, the missilery has significantly increased its capacity in Ukraine. New progressive launch vehicles Dnipro, Zenith-3SL and Cyclone-3 were mass-produced. Successful comprehensive tests of a new generation launch vehicles with Ukrainian constituents Cyclone-4 continue. Several artificial satellites have been produced and successfully launched into orbit by Ukrainian manufacturers [Ishchenko, 2018]. However, due to unsatisfactory government funding and a legislative ban on engaging private capital and business in space programs, Ukraine's space industry has declined.

Therefore, Ukrainian spacecraft manufacturers began to implement the basic rules of international space law upon their ratification by the Soviet Union, while domestic space law was practically absent. All legal regulation on the design, production, operation and launch of space technology was carried out on the basis of secret by-laws and administrative regulations.

\section{Regulations of public international space law applicable in Ukraine}

In the scientific literature, the regulations of space law are classified into international and domestic, which in turn are divided into public and private [Halunko \& Didenko, 2019]. Public international regulations of space law are universally recognized. Since their ratification by the Soviet Union, Ukraine has fully complied with them. Since independence (1991), Ukraine has been adhering to international space treaties signed and ratified by the USSR. For the reason that, according to the current legislation, Ukraine is the legal successor in title to the rights and obligations under international treaties of the USSR, which do not contradict the Constitution and interests of Ukraine [Pro pravonastupnytstvo, 1991], since each and every Soviet Union space treaties are such that meet these criteria.

Ukraine fully complies with these international space treaties. Namely: the Treaty on the Principles Governing States Activities in the Exploration and Use of Outer Space, including the Moon and Other Celestial Bodies (1967), the Agreement on the Rescue of Astronauts, the Return of Astronauts and the Return of Objects Launched into Outer Space (1968), the Convention on International Liability for Damage Caused by Space Objects (1972), the Convention on Registration of Objects Launched into Outer Space (1976).

During the period of independence, Ukraine has signed many international space treaties, multilateral and bilateral. The multilateral ones are: the Operating Agreement of the Intersputnik International Organization of Space Communications (2002), the Space Millennium: Vienna Declaration on Space and Human Development (1999).

Bilateral treaties are: the Agreement between the Government of Ukraine and the Government of the Federative Republic of Brazil on Technological safeguards Related to the Participation of Ukraine in Launches from the Alcântara Launch Centre (2002), the Note from the French Foreign Ministry to the Embassy of Ukraine in France on Ukraine's accession to the Missile Technology Control Regime (1998). Bilateral treaties, concluded with Russia, are although formally related to the international regulations of space law of Ukraine, but denounced or frozen as a result of sanctions because of the Russia's aggressive actions, which led to annexation of the Ukrainian region of the Autonomous Republic of Crimea and armed aggression in certain regions of Donetsk and Lugansk [Pro rishennya, 2015].

Distinctly, European Space Law should be mentioned. In this respect, Ukraine is a State that has signed, ratified and implemented the Agreement with the European Union, according to which Parties shall improve mutually beneficial dialogue in space. In addition, Chapter 
8 of this Agreement is entitled "Space" and provides for promoting mutually beneficial cooperation on civil space research and space applications, in particular in the following areas: global navigation satellite systems; earth surveillance and global monitoring; space science and exploration; applied space technologies, including launcher and propulsion technology [Uhoda, 2014]. Moreover, Ukraine, as a country seeking to become a full member of the $\mathrm{EU}$, voluntarily complies with high standards of public administration that are beneficial to Ukrainian citizens and achievable in terms of material resources and organizational capacity for the Government of Ukraine [Bandura, 2019].

Accordingly, the State of Ukraine, in compliance with the provisions of the Agreement under analysis or voluntarily, adheres to the following basic European space legislation: Decisions of the Council of the EU: on the conclusion of the Agreement between the European Space Agency and the European Union on the security and exchange of classified information (2008); on the International Code of Conduct for Outer Space Activities (2012); on the Framework for Space Surveillance and Tracking Support (2014); Resolution of the EU Council on the launch of the initial period of Global Monitoring for Environmental And Security [A European, 2001].

European Space Law on Earth Remote Sensing, including: EU Council Regulations on electronic Recording and reporting on fishing activities and on means of remote sensing (2006); on the measures to be undertaken by the Commission in 2008-2013 making use of the remote sensing applications developed within the framework of the common agricultural policy (2008) [Regulation, 2008].

European Space Law in space policy, in particular, is Resolutions of the Council of the European Union: on further development of the Community's satellite communications policy, especially with regard to the provision of, and access to, the space segment capacity (1994), on developing a coherent European space strategy (1999), the European Space Strategy (2000), on developing a common European space policy (2003); taking forward the European space policy (2008) [Reillon, 2008].

The European Space Law in navigation is most numerous, for example, the Resolutions of the EU Council: the European contribution to the development of the global satellite navigation system (1994), the agreement between the European Community, the European Space Agency and the European Organisation for the Safety of Air Navigation on developing Global Navigation Satellite Systems (1998), on the involvement of Europe in a new generation of satellite navigation services — Galileo-Definition phase (1999); EU Commission Decisions to set up an expert group on security of European GNSS systems (2009), to conclude an administrative agreement between the European Commission and the European GNSS Supervisory Agency on safety and exchange of classified information (2009), to set up the group of experts on the mission evolution of the European navigation satellite systems, "Mission Evolution Advisory Group" (2010) [Commission, 2010].

Standards of European Space Law in the field of telecommunications and satellite services are numerous, in particular: Decision of EEC on standardisation activities in the field of information and communication technologies (1986); Directives of the EEC Commission on competition in the markets for telecommunications services (1990), and on the adoption of standards for satellite broadcasting of television signals (1990); EU and European Parliament Directives on interconnection in telecommunications with regard to ensuring universal service and interoperability through application of the principles of Open Network security (1997); relating to telecommunications terminal equipment and satellite earth station equipment, 
including the mutual recognition of their conformity (1997); EU Commission Regulations laying down detailed provisions regarding satellite-based Vessel Monitoring Systems (2003), regarding competition in telecommunications terminal equipment markets (2007), on the selection of operators of pan-European systems providing mobile satellite communications services (2009) [Baza danykh, 2019].

Therefore, public international regulations of space law include the fundamental space international treaties that Ukraine has fully adhered to since the ratification by the USSR, Ukraine's multilateral and bilateral international space treaties with countries, except Russia, because treaties with a country-aggressor are frozen or denounced due to sanctions, and numerous European space laws.

\section{Regulations of private international space law}

For a long time, private international space laws have been a theoretical abstraction for Ukrainian private international law. For example, the current domestic space legislation did not allow private entities to engage in the space industry. Accordingly, no legal relationship could arise between the national space industry of Ukraine and private space enterprises.

The state of affairs changed after the relevant space law "On Space Activity" had been amended and added. According to it, private space organizations and institutions can become entities in space activities. Consequently, it is already intended to conclude the first contract between the national spacecraft manufacturer the State Enterprise Production Association Yuzhny Machine-Building Plant named after A. Makarov and a private aerospace firm Firefly Aerospace regarding the manufacture of rocket parts for about \$15 million [Taran, 2019].

Therefore, the amendments to the national relevant space law of Ukraine "On space activities" regarding engagement of private entities to such activities gave birth to the private international space law.

\section{Domestic regulations of space law of Ukraine}

Ukraine's space law is based on a number of laws. First of all, the relevant Law on Space Activity [Pro kosmichnu, 1996] providing for the general legal principles of space activities in Ukraine should be mentioned.

The law under analysis applies to all activities related to the exploration and use of outer space. Moreover, state regulation and administration in the field of space activities in Ukraine is carried out by establishment of the basic principles, guidelines and regulations of space activities by legislation, licensing of such activity, etc. [Pro kosmichnu, 1996].

The main drawback of the law under analysis was engagement of exclusively State agencies and enterprises in creation, launch and operation of space equipment. As a result, private investment in the Ukrainian space industry was absent that led to its decline. Only on October 2, 2019, this was corrected; in accordance with the Law of Ukraine "On Amendments to Certain Laws of Ukraine Regulating Space Activity" [Pro vnesennya, 2019], institutions and organizations of any form of ownership may engage in research, development, production, operation, maintenance of launch and return of spacecraft.

This gives significant opportunities for citizens of Ukraine, foreigners, national and foreign legal entities to use the space potential available in Ukraine. 
Therefore, the new national space law gives the Ukrainian space industry a new chance for development through private investment.

In addition to the Law of Ukraine "On space activities", the space industry is regulated by other laws of Ukraine, in particular "On State secrets" (1994), "On State control over international transfers of military and dual-use goods" (2003), "On International Treaties of Ukraine" (2004), “On State property management" (2006), "On licensing of economic activities" (2015), "On administrative services" (2012), and others.

Among the by-laws in the field of space there is the "Regulation on the State Space Agency of Ukraine", which was approved by the Resolution of the Government of Ukraine. According to it this Agency is the central body of executive power, directed and coordinated by the Government of Ukraine, which ensures the formation and implementation of State policy in the field of space activities [Polozhennya, 2015].

Therefore, domestic regulations of Ukraine's space law are based on the relevant Law on space activities, several other laws, and a dozen by-laws.

\section{Current state of affairs in domestic space legislation of Ukraine}

For the purpose of State support for the space industry, a special Law of Ukraine "On State support for space activities" was adopted in 2000 [Pro derzhavnu, 2000]. It regulates entities carrying out space activities in accordance with relevant law. According to Ukrainian legislators, this approach should ensure the development of scientific, technical, technological and industrial potential, increase export potential, competitiveness of the space industry and become a guarantee of attracting investment in the space industry improvement.

However, this did not happen, because only State agencies and organizations could engage in space activities for a long time. Now this has been adjusted. On January 29, 2020, the amendments to the relevant Law of Ukraine "On Space Activity" are coming into force. From that date, private entities will be able to engage in space activities by filing a declaration of their will to engage in commercial space activities. Such declaration shall be submitted to the Space Agency of Ukraine not less than 5 working days before commencement of such activity. At the same time, administrative responsibility is imposed for conducting commercial activities without submitting this declaration or providing false or incomplete information [Pro vnesennya, 2019].

For the main types of space activities, permits shall be introduced that the Space Agency of Ukraine will grant within 90 calendar days from the date of the receipt of an application for the term of space activity object operation.

The types of space activities that can be carried out under permits only include: testing of launch vehicles, including their units and components and spacecraft; launching launch vehicles and/or spacecraft; controlling spacecraft in Earth orbit or in outer space; returning spacecraft and/or their rotating components from Earth orbit or outer space to Earth. In addition, the amendments to the Law of Ukraine "On Insurance" include the compulsory types as follows: civil liability insurance of subjects of space activity and liability insurance regarding the risks associated with the preparation for launching spacecraft at the spaceport, launching and operating it in outer space. All other types of space activity risk insurance should be voluntary [Pro vnesennya, 2019]. 
Therefore, the legislator has made an attempt to revive the Ukrainian space industry. Generally, positive changes to the legislation governing space activities have been adopted. Nevertheless, some challenges exist in implementing these changes.

\section{Conclusions}

The specificities of law-making in Ukraine is in the requirement of prior development and adoption of subordinate legal regulations, which specify details of the rules of laws, before the laws take effect. As a general rule, by-laws should not contradict the law. However, in Ukraine, as a rule, central executive authorities both develop by-laws and implement them in the future. Regarding the amendments to the relevant Law of Ukraine "On Space Activity," the State Space Agency of Ukraine will develop details and clarification of subordinate by-laws. However, this State agency with controlling functions in the space industry requires "more trust" [Honcharuk, 2019]. Therefore, this could lead to the emasculation of new progressive provisions of the relevant space law. Accordingly, Ukrainian civil society and space actors should help this national space regulator to become a more open and effective public administration entity.

However, the level of democracy in Ukraine is high, the media is strong, and civil society is experienced in counteracting corruption. Therefore, that Ukraine's space industry will start to develop dynamically due to the private sector.

The article reveals the latest doctrine of space law in Ukraine, consisting of international and domestic regulations of space law, which are both public and private in nature. However, within one article, it is not possible to reveal fully all the nuances of the development of space law of Ukraine under current conditions. Further thorough analysis of European laws applied by Ukraine and related to the regulation of space activities is still required.

\section{References}

A European Approach to Global Monitoring for Environment and Security (GMES): Towards Meeting Users' Needs Joint Working Document by Staff of the European Commission and the European Space Agency, 2001. https://www.unece.org/fileadmin/DAM/env/ europe/gmes.e.pdf

Bandura, Svitlana. Administratyvno-pravovi zasady administratyvnoho prava Ukrayiny ta krayin-uchasnyts' YES (Hretsiya, Bolhariya, Ispaniya, Rumuniya). OLDI-PLUS, 2019. $136 \mathrm{p}$.

Baza danykh kosmichne zakonodavstvo. Derzhavne kosmichne ahentstvo Ukrayiny, 2019. http://www.nkau.gov.ua/ua/legislation

Biographies Mikhail Yangel. Design Office “Yuzhnoye”, 2019. https://www.yuzhnoye.com/ en/company/history/yangel.html

Commission decision of 6 October 2010 setting up the group of experts on the mission evolution of the European navigation satellite systems, the 'Mission Evolution Advisory Group'. Official Journal of the European Union, 2010. https:/eur-lex.europa.eu/LexUriServ/ LexUriServ.do?uri=OJ:C:2010:271:0002:0003:EN:PDF

Design Office "Yuzhnoye", 2019. https://www.yuzhnoye.com/en

Dovhal', Serhiy. Yoho Raketna Velychnist'. Ukrayina moloda, 25.10.2011. https://www. umoloda.kiev.ua/number/p-0/?q= $\%$ D1 $\% 80 \% \mathrm{D} 0 \% \mathrm{~B} 0 \% \mathrm{D} 0 \% \mathrm{BA} \% \mathrm{D} 0 \% \mathrm{~B} 5 \% \mathrm{D} 1 \% 82 \%$ D0\%BD $\%$ D0 $\%$ B0+\%D0\%B2\%D0\%B5\%D0\%BB $\%$ D0\%B8\%D1\%87\%D0\%BD $\%$ D $1 \% 96 \% \mathrm{D} 1 \% 81 \% \mathrm{D} 1 \% 82 \% \mathrm{D} 1 \% 8 \mathrm{C}$ 
Gorbulin, Volodymyr. Istorychna osobystist': do 100-richchya vid dnya narodzhennya M. K. Yanhelya. Science And Science of Science, 2011. № 4. pp. 5-15.

Halunko, Valentyn and Serhii Didenko. Private International Space Law. Philosophical and Legal Factors of Approval by the World Community. Philosophy and Cosmology, Volume 22, 2019: 16-23. https://doi.org/10.29202/phil-cosm/22/2

Honcharuk, Oleksiy. Chomu zvil'nyly Dehtyarenka z Derzhavnoho Kosmichnoho Ahentstva, 2019. https:/www.depo.ua/ukr/politics/goncharuk-skazav-chomu-zvilnilidegtyarenka-z-derzhavnogo-kosmichnogo-agentstva-201911061058367

Ishchenko, Anastasiya. Kosmichna Ukrayina: Dosyahnennya i Peremohy. Segodnya, 2018. https://ukr.segodnya.ua/ukraine/kosmicheskaya-ukraina-dostizheniya-i-pobedy1164738.html

Malysheva, Natalia. State and Prospects for the Development of Space Law Research. Institute of State and Law. V. M. Koretsky, 2011. Volume 25. pp. 223-226.

Polozhennya pro Derzhavne kosmichne ahent·stvo Ukrayiny. Postanova Uryadu Ukrayiny vid 14 travnya 2015 r. № 281. Derzhavne kosmichne ahentstvo Ukrayiny. http://www. nkau.gov.ua/docs/pravo_new/Data/01_okd/012_zdentkpu/0123_nakmu/postanovy/ Pro\%20zatverdzhennya $\%$ 20Polozhennya $\% 20$ pro\%20Derzhavne $\%$ 20kosmichne $\% 20$ ahen...\%20_\%20vid\%2014.05.2015\%20№\%20281.htm

Pro administratyvni posluhy. Zakon Ukrayiny, 2013. https://zakon.rada.gov.ua/laws/ main/5203-17

Pro kosmichnu diyal'nist'. Zakon Ukrayiny, 1996. https://zakon.rada.gov.ua/laws/show/502/96-vr

Pro pravonastupnytstvo Ukrayiny. Zakon Ukrayiny, 1991. https:/zakon.rada.gov.ua/laws/ show/1543-12

Pro derzhavnu pidtrymku kosmichnoyi diyal'nosti. Zakon Ukrayiny, 2000. https://zakon.rada. gov.ua/laws/show/1559-14

Pro rishennya Rady natsional'noyi bezpeky i oborony Ukrayiny vid 2 veresnya 2015 roku "Pro zastosuvannya personal'nykh spetsial'nykh ekonomichnykh ta inshykh obmezhuval'nykh zakhodiv (sanktsiy)’”. Ukaz Prezydenta Ukrayiny №549, 2015. https://www.president. gov.ua/documents/5492015-19437

Pro vnesennya zmin do deyakykh zakoniv Ukrayiny shchodo derzhavnoho rehulyuvannya kosmichnoyi diyal'nosti. Zakon Ukrayiny, 2019. https://zakon.rada.gov.ua/laws/ show/143-20

Pryvatni pidpryyemtsi zmozhut' zaymatysya kosmichnoyu diyal'nistyu. Liha Zakon, 2019. https://jurliga.ligazakon.net/ua/news/189818_privatn-pdprimts-zmozhut-zaymatisyakosmchnoyu-dyalnstyu-priynyato-zakon

Regulation (EC) № 110/2008 of the European Parliament and of the Council of 15 January 2008 on the definition, description, presentation, labelling and the protection of geographical indications of spirit drinks and repealing Council Regulation (EEC) № 1576/89, 2008. https://eur-lex.europa.eu/legal-content/EN/ALL/?uri=CELEX\%3A32008R0110

Reillon, Vincent. European Space Policy. Historical Perspective, Specific Aspects and key Challenges. Members' Research Service, 2017. http://www.europarl.europa.eu/ RegData/etudes/IDAN/2017/595917/EPRS_IDA(2017)595917_EN.pdf

Taran, Victor. Yudmash Will Receive \$ 15 Million from US Firefly. UNIAN, 2019. https:// www.unian.ua/economics/other/10738077-pivdenmash-otrimaye-zamovlennya-vidamerikanskogo-firefly-na-15-milyoniv-ekspert.html 
The Legend of Domestic Rocket Designing Extended Session of Coordinating Council for Organizing of Joint Work of Yangel "Yuzhnoye" Design Office and Scientific Institutions of NAS of Ukraine Devoted to $90^{\text {th }}$ Anniversary of Academician V.F. Utkin. Visnyk of the NAS of Ukraine, 2013. № 12. p. 5. http://www.visnyk-nanu.org.ua/en/ node/1204

Uhoda pro asotsiatsiyu mizh Ukrayinoyu, z odniyeyi storony, ta Yevropeys'kym Soyuzom, Yevropeys'kym spivtovarystvom z atomnoyi enerhiyi i yikhnimy derzhavamy-chlenamy, z inshoyi storony. Verkhovna Rada Ukrayiny, 2014. https://zakon3.rada.gov.ua/laws/ show/984_011 